\title{
Relationship Distance Analysis of Swamp Buffalo Bubalus bubalis Phenotype in Three Regions in East Java, Indonesia
}

\author{
Ardyah Ramadhina Irsanti Putri ${ }^{1}$, Agus Budiarto ${ }^{1, *}$, Gatot Ciptadi ${ }^{1}$ and Rescha \\ Saputra $^{1}$
}

\author{
${ }^{1}$ Faculty of Animal Science, Brawijaya University, Malang \\ "Corresponding author.Email: agusfpt@ub.ac.id
}

\begin{abstract}
Swamp buffalo (Bubalus bubalis) is one of the potential animal livestock for meat production but is still not popular as meat compared to both cattle and goats. Buffalo farmers, especially in Malang Regency, mostly used buffalo for ploughing the rice fields with traditional care and unprogrammed breeding. This initial research aims to study the relationship distance of swamp buffalo in three regions in East Java, Indonesia based on their phenotypic characteristics. A total of 60 bulls aged 60-90 months were used from three region in East Java, including 20 bulls from Banyuwangi, Madiun, and Malang Regency each. Samples were observed for their color in body, muzzle, lower legs, tail hair, eye circumference, and aberrant body color. The data was analyzed using PAST software with UPGMA and Euclidean distance, to obtain a dendrogram. The result of the dendrogram, from three regions in East Java, were categorized into two groups, A and B (distance 2.5). Group A, which were all from Malang Regency, showed high similarity, while in group B, between Madiun and Banyuwangi has more in common color characters.
\end{abstract}

Keywords: Buffalo, inbreeding, characters, phenotype, cluster.

\section{INTRODUCTION}

Swamp buffalo (Bubalus bubalis) is one type of livestock that dominates buffalo breeds in Indonesia with around 95 percent. Swamp buffalo generally have blackish-brown coat color, solid body conformation, relatively short body and legs, broad belly with a long neck. The face has a flat, short forehead with a broad muzzle. The shape of the horns is usually curved backward. The body weight is lighter than the river buffalo [1]. Buffalo populations that exist throughout the world today come from India which was the result of the domestication process of wild buffalo (Bubalus arnee). However, this type of buffalo is less desirable as a source of meat, especially on Java Island. Most of the swamp buffalo are used by farmers because of their ability to pull plows to facilitate agricultural work like ploughing the rice fields.

The productivity of buffaloes tends to decrease from year to year. According to data from the Central Bureau of Statistics (BPS) in East Java, the buffalo population from 2009 to 2017 did not experience significant changes [2]. Among the breeders themselves, the lack of care, traditional small farmer management [3] and breeding programs for swamp buffalo can also cause a decline in the quality and performance in the future. The buffalo parental which has good reproductive and growth performance needs to be used as a source of replacement stock so that the buffalo population can be increased. The strategy for the development and improvement of buffalo reproduction can be done by holding a program, including the artificial insemination (AI) program so that it can help reduce the occurrence of inbreeding between breeders in an area [4].

Observations of phenotypic characters especially in their colors can be used as initial research because variations can be assessed quickly when compared to other characters in determining kinship within a species. Characterization of the diversity of morphological characters and kinship in swamp buffalo is very 
important for the sustainability of germplasm conservation and as a basis for determining breeding program policies in the short, medium, and long term of swamp buffalo in East Java, Indonesia.
Clusters are joined based on the average distance between all members in the two groups. The Euclidean distance (between rows) is a robust and widely applicable measure. Distance is converted to similarity by changing

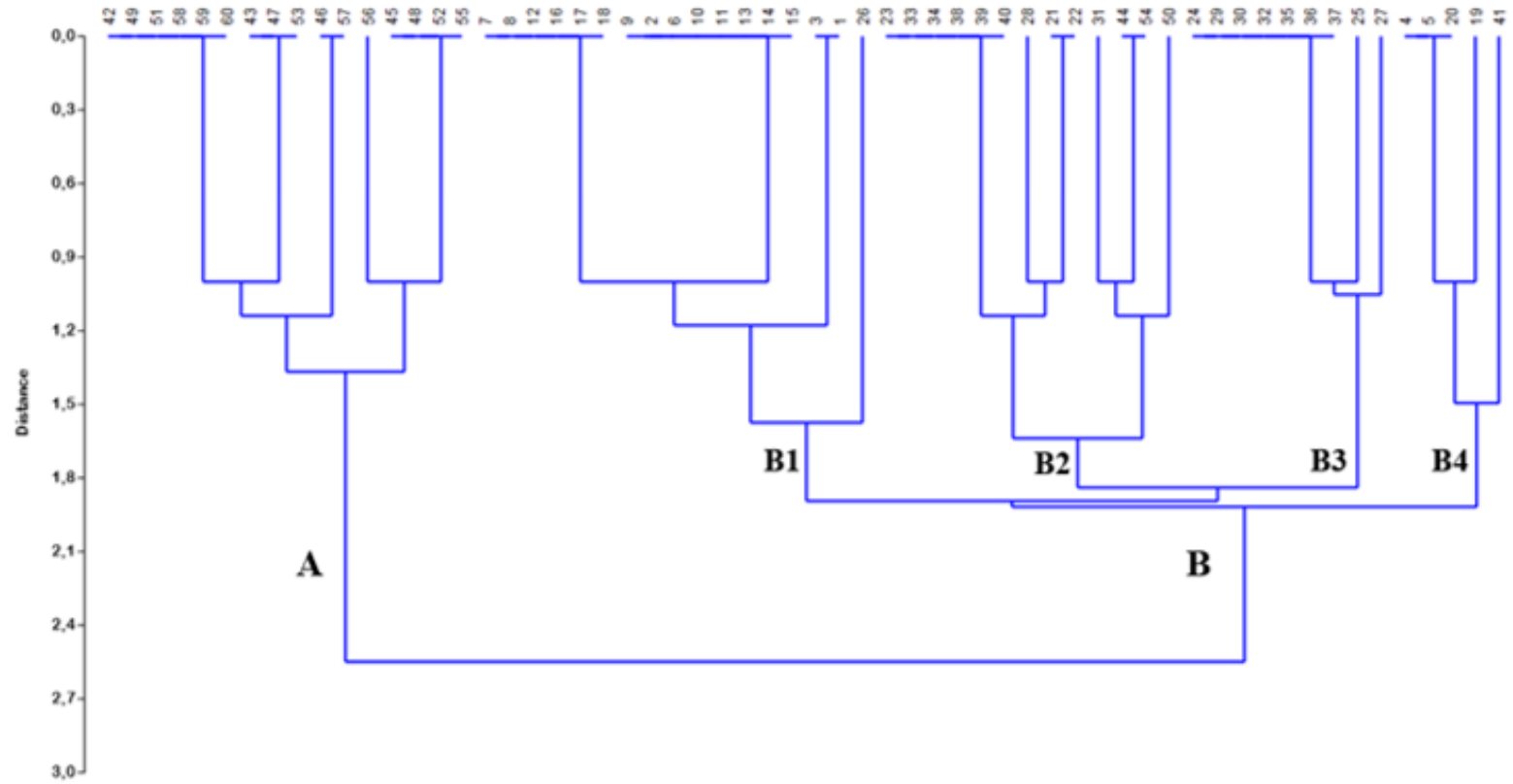

Figure 1. Dendogram analysis results on swamp buffalo sample number 1-60

\section{MATERIAL AND METHODS}

A total of 60 bulls of swamp buffaloes aged 60-90 months from 3 areas in East Java, including 20 bulls from Banyuwangi (number 1-20), 20 bulls from Madiun (number 21-40), and 20 bulls from Malang Regency (number 41-60) were observed. Samples were randomly determined from several farmers. This study used a descriptive method with direct observation techniques on the buffaloes. Observations in their color including; body, muzzle, lower legs, tail hair, eye circumference, and aberrant body color. The data obtained were processed into binary data and computed in Paleontological Statistics (PAST) software with Unweighted-Pair Group Method with Arithmetic Means (UPGMA) [5] and Euclidean distance, to obtain a dendrogram of relationship distance.

\section{RESULT AND DISCUSSION}

Cluster analysis yields a hierarchical grouping using multivariate data sets. The hierarchical clustering routine produces a 'dendrogram' showed how the data was clustered. The results of the dendrogram showed that 60 male buffaloes were observed formed 2 large clusters with 2.5 distance where cluster A came from the Malang district, while cluster B came from Madiun and Banyuwangi (Figure 1), with a coefficient correlation of 0.8992. From cluster B, it is divided into 4 sub-clusters, namely B1, B2, B3, and B4. the sign [6]. In Figure 1. clostest distance between B2 and B3 are 1.95 , B1 with group B2 and B3 are 2.1, and between group B1 and B4 is 2.2. Sub-cluster B1 is dominated by buffalo observed from Banyuwangi $94 \%$ and $6 \%$ from Madiun. Sub-cluster B2 is dominated by buffalo from Madiun as much as $76.9 \%$ and $23.1 \%$ from Malang Regency. Sub-cluster B3 100\% comes from buffalo samples from Madiun. The last sub-cluster B4, $80 \%$ came from Banyuwangi with $20 \%$ from Malang Regency. The UPGMA method begins with the calculation of the branch length among the closest related data, then averages the distance between the sample or sample group and to the next sample or sample group and continues until all samples are included in the tree [7].

In Malang Regency, the body color is dominated by dark grayish, when compared to the Madiun and Banyuwangi areas which are dominated by a lighter color, grayish-white. A similar study revealed that the color of the buffalo skin in the Malang area from the total observations all had dark gray skin color and did not form variations until now [8]. The color of the muzzle in Malang and Madiun Regencies is mostly white, in contrast to Banyuwangi, which all have black on the muzzle. Then for the color of the legs of the buffalo, in Banyuwangi, $90 \%$ is white, in Madiun $50 \%$ is black, the remaining $50 \%$ is white, while in Malang Regency, the color of the legs is predominantly white.

Relationship study is one of the fundamental principles for grouping each individual into a group of 
categories. The diversity of horn shapes from the observations showed that there were $8 \%$ of bucks had no horns, 55\% had horns that curled backward, and the remaining $37 \%$ had pointed horns.

The distribution of the buffalo population is usually in groups in each area. Buffalo population groups are quite large scattered around the areas of Aceh, North Sumatra, West Sumatra, Jambi, South Sumatra, Banten, Kudus, Mataram, Sumbawa, Maluku, Toraja (South Sulawesi), and South Kalimantan [9]. In East Java, buffalo is less popular than in West Java, Banten Province, along the north coast from Tangerang, Serang to Cilegon. Lebak to the west and south coasts of Banten, residents still faithfully raise and using buffalo in their fields. Due to differences in environmental conditions and maintenance by local breeders, buffalo from each of these areas will have slight differences [10] that are not so significant in terms of their physical characteristics.

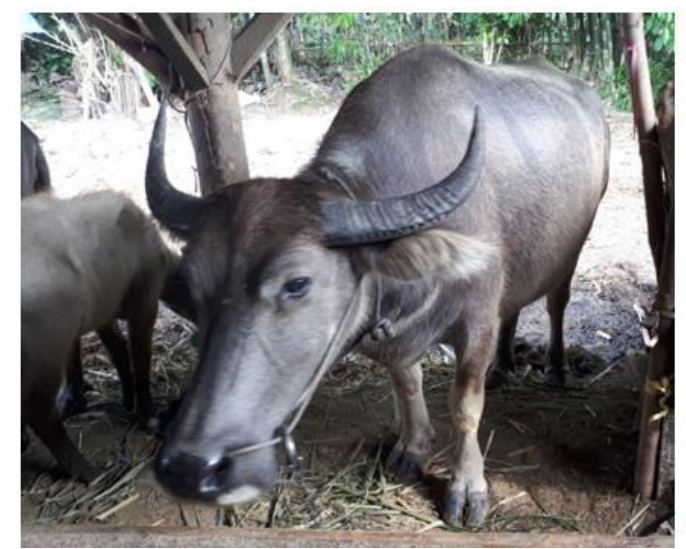

Figure 2. Swamp buffalo from Malang Regency

Unlike the buffalo in Sulawesi. The most popular striped swamp buffalo from Sulawesi is found around the Toraja area. Striped buffalo have morphological characteristics that are somewhat different from other swamp buffalo. In general, striped buffalo have a reddish-white and black color pattern. In addition, generally, striped buffalo also have white eyes, which are different from swamp buffalo in general [11]. The advantage of the swamp buffalo is its high adaptability even with a poor-quality feed. However, due to poor maintenance, the population tends to decline [12]. Further and advanced research is needed to find out more about the relationship between regions as a step to determine breeding programs to increase livestock productivity regarding production and reproduction in swamp buffalo.

\section{CONCLUSION}

The conclusion from the results of color observations in this study, from three regions in East Java were divided into 2 groups, A and B. Group A, which were all from Malang Regency, showed that in one region there was a high similarity, while in group B, between Madiun and Banyuwangi has more in common color characters.

\section{REFERENCES}

[1] Yendraliza. 2012. Performance Characteristic of Male Swamp Buffalo in Regency of Kampar. Agrinak 2 (1): 17-21

[2] Badan Pusat Statistik (BPS) Provinsi Jawa Timur. 2018. Populasi Kerbau menurut Kabupaten/ Kota di Jawa Timur, 2009-2017

[3] Ciptadi, Gatot \& Nasich, M \& Budiarto, Agus \& Nurgiartiningsih, V. 2012. Pakistan Veterinary Journal The Estrus Synchronization Response Following PGF $2 \alpha$ Treatment in Indonesian Madura Cattle with Different Body Condition Scores. Pakistan Veterinary Journal. 83186783. 2074-7764.

[4] Budiarto, A., Ciptadi, G., Hakim, L., Susiati, Karima, N.K. Hisam, M.H. 2019. The productivity of female swamp buffaloes (Bubalus bubalis) in East Java, Indonesia. IOP Conf. Series: Earth and Environmental Science 247: 012029

[5] Li L, Zhang J, Zhu JQ, Gu S, Sun Q, Zhou GM, Fu CX, Li Q, Chen LY, Li DX, Liu SJ, Yang ZR. Genetic diversity of nine populations of the black goat (Capra hircus) in Sichuan, PR China. Zoolog Sci. 2006 Mar;23(3):229-34. doi: 10.2108/zsj.23.229. PMID: 16603815.

[6] Hirkhorshidi AS, Aghabozorgi S, Wah TY (2015) A Comparison Study on Similarity and Dissimilarity Measures in Clustering Continuous Data. PLoS ONE 10(12): $\quad$ e0144059. https://doi.org/10.1371/journal.pone.0144059

[7] Nihar Ranjan Chattopadhyay. 2017. Chapter 10 Genetic Variation and Phylogenetic Relationship Among the Two Different Stocks of Catla (Catla catla) in the Indian State of Orissa Based on RAPD Profiles. In : Induced Fish Breeding (Nihar Ranjan Chattopadhyay). Academic Press . pp. 267-301

[8] Performan Reproduksi Kerbau Lumpur (Bubalus bubalis) di Kabupaten Malang. 2013. DW Suhendro, G Ciptadi, S Suyadi. Ternak Tropika Journal of Tropical Animal Production 14(1):1-7

[9] Diwyanto, K. dan H. Handiwirawan. 2006. Strategi pengembangan ternak kerbau: aspek penjaringan dan distribusi. Prosiding lokakarya nasional usaha ternak kerbau mendukung program kecukupan daging sapi. 2006. Pusat Penelitian dan Pengembangan Peternakan, Bogor.

[10] Ciptadi, G., Budiarto, A., Hakim L., Putri, A.I., Finawati, P., Ubaidillah, M.H. 2019. The reproductive characters of swamp buffalo in small 
holder farm in East Java, Indonesia. IOP Conf. Ser.: Earth Environ. Sci. 247:012019

[11] Sari, E.M. Abdullah, M.A.N. Koesmara, H and Dagong, M I A. 2021. Phylogenetic analysis of Gayo and Toraya buffalo breed of Indonesian through mitochondrial D-loop region. IOP Conf. Series: Earth and Environmental Science 788: 012013

[12] Budiarto, A., Ciptadi, G., Hakim, L., Putri, A.I. 2019. Reproductive performance and fertility index of swamp buffalo (Bubalus bubalis) in ngawi regency, east java. IOP Conf. Series: Journal of Physics: Conf. Series 1146: 012024 